\title{
Jejunal mucosal immunoglobulin-containing cells and jejunal fluid immunoglobulins in adult coeliac disease and dermatitis herpetiformis
}

\author{
M. LANCASTER-SMITH, PARVEEN KUMAR, R. MARKS, M. L. CLARK, AND \\ A. M. DAWSON
}

From the Department of Gastroenterology, St Bartholomew's Hospital, London, and

St John's Hospital for Diseases of the Skin, London

SUMMARY Immunoglobulin-containing plasma cell densities in the jejunal mucosa and serum and jejunal fluid immunoglobulins have been measured in patients with adult coeliac disease and dermatitis herpetiformis with and without jejunal mucosal abnormality. Studies were performed in patients before and after treatment of the jejunal lesion.

Total immunofluorescent plasma cells were increased in untreated adult coeliac disease and dermatitis herpetiformis patients with jejunal lesions, but in general the normal predominance of IgA $>$ IgM > IgG was found. There was no difference from controls in IgA-containing cells in the two conditions before or after treatment. The numbers of IgM-containing cells were significantly increased both before and after treatment in groups of patients with adult coeliac disease and dermatitis herpetiformis who had jejunal lesions. IgG-containing cells were significantly raised in only the before-treatment groups. Patients with dermatitis herpetiformis without jejunal lesions, even whilst on gluten-containing diets, had normal numbers of immunoglobulin-containing cells. IgA and IgM jejunal fluid immunoglobulins were significantly raised in dermatitis herpetiformis and adult coeliac disease.

It is concluded that patients with dermatitis herpetiformis with jejunal morphological abnormality have a comparable immunological disturbance of the jejunal mucosa to that found in adult coeliac disease.

The association between adult coeliac disease and dermatitis herpetiformis has been further supported by recent reports of similar immunological findings. Changes in serum (Fry, Keir, McMinn, Cowan, and Hoffbrand, 1967; Fraser, Dick, and Crichton, 1969; Hobbs and Hepner, 1968; Asquith, Thompson, and Cooke, 1969) and jejunal fluid immunoglobulins (Douglas, Crabbé, and Hobbs, 1970; McClelland, Barnetson, Parkin, Warwick, Heading, and Shearman, 1972), circulating immune complexes (Mowbray, Hoffbrand, Holborow, Seah, and Fry, 1973; Doe, Booth, and Brown, 1973), and tissue antibodies (Seah, Fry, Hoffbrand, and Holborow, 1971) suggest that immunological factors may well be involved in the pathogenesis of these two conditions.

Abnormalities of the plasma cell densities in the lamina propria of the jejunum using immunofluorescent techniques have been reported in adult Received for publication 12 February 1974. coeliac disease (Douglas et al, 1970; Søltoft; 1970; Pettingale, 1971) but comparable information is not available for dermatitis herpetiformis. In view of the fact that similar though usually less severe jejunal morphological changes occur in dermatitis herpetiformis (Marks, Shuster, and Watson, 1965; Marks, Whittle, Beard, Robertson, and Gold, 1968; Brow, Parker, Weinstein, and Rubin, 1971), we have compared the densities of immunoglobulin-containing cells in these two conditions and correlated them with morphology and treatment. A further study was also made of the concentrations of jejunal fluid and serum immunoglobulins in both diseases

\section{Patients and Methods}

In all studies the diagnosis of adult coeliac disease was made on clinical and biochemical evidence of malabsorption, villous atrophy of the jejunum, and 
by previous or subsequent response to a gluten-free diet. Dermatitis herpetiformis was diagnosed on the clinical and histological features of the rash and its response to Dapsone.

Measurements of immunoglobulin-containing cells and jejunal fluid immunoglobulins were performed in different groups of patients as described below.

\section{IMMUNOFLUORESCENCE STUDIES ON} JEJUNAL MUCOSA

\section{Dermatitis herpetiformis}

Fourteen biopsies from 11 patients with abnormal jejunal morphology were examined; 10 showed partial villous atrophy with villous heights ranging from 137 to 280 microns (normal $>330$ microns) and surface cell heights from 21 to 26 microns (normal > 29 microns), and four had subtotal changes with villous heights ranging from 0 to 100 microns and surface cell heights from 15 to 17 microns. Eight were from patients on unrestricted diets, three were from patients who had been on gluten-free diets for three to four months, and three from patients receiving prednisolone.Of these patients, two were studied before and after taking a gluten-free diet for four to six months. Biopsies from three patients with dermatitis herpetiformis with normal jejunal morphology whilst on normal diets were also studied.

\section{Adult coeliac disease \\ Thirteen biopsies from 11 patients were studied, seven before starting a gluten-free diet and six after gluten restriction of one to six years. Of these patients, two were studied before and after taking a gluten-free diet for six and eight months. All of the untreated patients had subtotal villous atrophy with villous heights ranging from 0 to 98 microns and surface cell heights from 13 to 22 microns, and the treated group had partial villous atrophy, with villous heights ranging from 175 to 320 microns and surface cell heights from 20 to 26 microns.}

\section{Controls}

Specimens were obtained from eight patients of comparable age to the above groups, who were being investigated for gastrointestinal symptoms. All had normal small bowel histology and no evidence of immunological disturbance

\section{Methods}

Biopsies were obtained by Crosby capsules in fasting subjects from the duodeno-jejunal flexure. Half of the tissue was immediately snap frozen, embedded in Ames OCT compound and stored at minus $70^{\circ} \mathrm{C}$. The remainder of the specimen was processed for staining with haematoxylin and eosin and methyl green pyronine, which was used to facilitate the identification of plasma cells. Sections, 6 microns thick, were prepared in a Bright's cryostat at minus $25^{\circ} \mathrm{C}$. The sections were dried at room temperature for one and a half to two hours. Antisera to human IgA, IgG, and IgM conjugated with fluorescein isothiocyanate and diluted with Coons buffer $1: 30,1: 20$, and $1: 20$ respectively were placed on the sections. After 20 minutes the sections were washed in changes of Coons buffer for a minimum of one hour. Excess moisture was removed with filter paper and the sections were mounted in a $1: 5$ solution of buffered glycerol.

The antisera had been shown to be monospecific to their corresponding antigens before and after conjugation by the manufacturers (Behringwerke, Hoechst Pharmaceuticals Ltd). Specificity of staining by each conjugate was confirmed in this study by the blocking technique of Nairn (1964).

The stained sections were examined with a Leitz Ortholux microscope fitted with a darkground Toric lens condenser. A mercury vapour light source was used in conjunction with Balzer FITC 3 and Leitz K530 filters. A Leitz Orthomat automatic camera was attached to the microscope. Quantitative measurement of the cellular immunofluorescence was made by taking Kodak Ektachrome daylight film slides of at least three high-power fields for each immunoglobulin class on each biopsy. The slides thus obtained were projected onto graph paper and the areas of total lamina propria and cellular immunofluorescence were traced. The areas of cellular fluorescence were expressed as percentages of the total area of lamina propria.

\section{JEJUNAL FLUID IMMUNOGLOBULINS}

\section{Dermatitis herpetiformis}

Of 14 patients studied, two had subtotal villous atrophy of the jejunum and 12 had partial villous atrophy. Three were on a gluten-free diet and 11 were on a normal diet.

\section{Adult coeliac disease}

Fourteen patients were studied and at the time of investigation five patients had been on a gluten-free diet from 10 months to four years and nine were untreated.

\section{Controls}

These consisted of 14 subjects undergoing investigation for possible gastrointestinal disease and all had normal small bowel morphology.

\section{Methods}

Fasting samples of jejunal juice were collected from 
the duodeno-jejunal flexure via a Crosby capsule before firing. Trasylol was added immediately and samples were snap frozen and stored at minus $30^{\circ} \mathrm{C}$.

Immunoglobulin concentrations (IgA, IgG, IgM) were measured with Hyland low-level plates, using standards supplied by the manufacturer. The lowest levels of accurate estimation by this technique was taken as $4 \mathrm{mg}$ per $100 \mathrm{ml}$. When immunoglobulin was detectable but below $4 \mathrm{mg}$ per $100 \mathrm{ml}$ an arbitrary value of $2 \mathrm{mg}$ per $100 \mathrm{ml}$ was given to that specimen. The IgA standards were of the $7 \mathrm{~s}$ category. The approximated IgA levels recorded in the results, however, are adjusted (Brandtzaeg, Fjellanger, and Gjeruldsen, 1970), assuming the majority of IgA to be in the 11s form. This has been done to facilitate comparison with previous studies in which $11 \mathrm{~s}$ standards have been used.

Serum immunoglobulins were measured in all patients studied by the single radial diffusion technique using immunoplates supplied by Hyland Laboratories.

\section{Results}

\section{IMMUNOFLUORESCENCE ON JEJUNAL}

\section{$M U \cos A$}

Details of the results are shown in figures 1-4. These may be summarized as follows:

Compared with controls the total numbers of immunofluorescent cells were increased in both disorders in untreated patients with abnormal jejunal morphology. There was no significant difference between patients on gluten-free diets or prednisolone, untreated patients with dermatitis herpetiformis with normal jejunal histology, and controls. Biopsies were also stained with methyl green pyronine and quantitation of cells performed by the above technique also showed that the areas occupied by plasma cells were increased in untreated patients with both conditions.

\section{IgA-containing cells}

Adult coeliac disease and dermatitis herpetiformis groups before or after treatment did not differ significantly from each other or controls.

\section{IgM-containing cells}

IgM cells were greatly increased to a comparable degree in patients with adult coeliac disease on normal diets and patients with dermatitis herpetiformis with jejunal abnormality on normal diets compared with controls $(P<0.002)$. The numbers of cells were reduced to the same extent in both groups of patients on a gluten-free diet or prednisolone, but there remained a difference between these patients and controls $(P<0.05)$. Dermatitis herpetiformis patients without jejunal lesions on normal diets did not differ from controls.

\section{IgG-containing cells}

These were increased to a comparable degree in adult coeliac disease patients on normal diets and dermatitis herpetiformis patients with jejunal morphological abnormality on normal diets compared with controls $(P<0.01)$. There were no significant differences between treated patients with adult coeliac disease and dermatitis, herpetiformis, untreated dermatitis herpetiformis patients without jejunal lesions and controls.

\section{RELATIONSHIP OF IMMUNOFLUORESCENT}

CELLS TO JEJUNAL MORPHOLOGY

In adult coeliac disease the increase in IgM and IgG cells was greater in patients with subtotal villous atrophy, all of whom were on normal diets, than in those with partial villous atrophy, who were taking gluten-free diets. In contrast, in dermatitis herpetiformis the severity of the mucosal lesion was not exclusively related to the dietary status of the patient and comparable increases in IgM and IgG cells were found in patients with subtotal and partial villous atrophy.

\section{PATIENTS STUDIED BEFORE AND AFTER}

\section{TREATMENT}

IgM cells in the four patients (two in each 'group) studied before and after treatment decreased markedly in all cases following treatment. The mean for the IgM fluorescent area calculated from these four patients fell from $7 \cdot 7$ to $3.9 \%$ of the total area of lamina propria. For IgA and IgG cells there was a reduction in three patients (two adult coeliac disease and one dermatitis herpetiformis) after treatment but in one patient with dermatitis herpetiformis the reverse occurred. The respective means for the IgA and IgG fluorescent areas calculated from all four cases fell from 13 to $9 \%$ and 1.8 to $1.3 \%$ of the total area of lamina propria.

JEJUNAL FLUID IMMUNOGLOBULINS

The concentrations of jejunal fluid immunoglobulins in the three groups are shown in the table.

\begin{tabular}{lrrr}
\hline Immunoglobulins & Controls & $\begin{array}{l}\text { Adult Coeliac } \\
\text { Disease }\end{array}$ & $\begin{array}{l}\text { Dermatitis } \\
\text { Herpetiformis }\end{array}$ \\
\hline IgA & $13.3 \pm 2.0$ & $26.6 \pm 5.4$ & $64.3 \pm 18.0$ \\
IgG & $1.6 \pm 0.5$ & $2.7 \pm 0.5$ & $3.7 \pm 0.5$ \\
IgM & $2.3 \pm 1.0$ & $6.6 \pm 2.9$ & $15.0 \pm 5.5$ \\
\hline
\end{tabular}

Table Immunoglobulins in jejunal fluid ${ }^{1}$

${ }^{2}$ Means \pm standard errors are shown in $\mathrm{mg}$ per $100 \mathrm{ml}$.

$\operatorname{Ig} A$

Patients with dermatitis herpetiformis had sig- 
JEJUNAL CELLULAR IMMUNOFLUORESCENCE

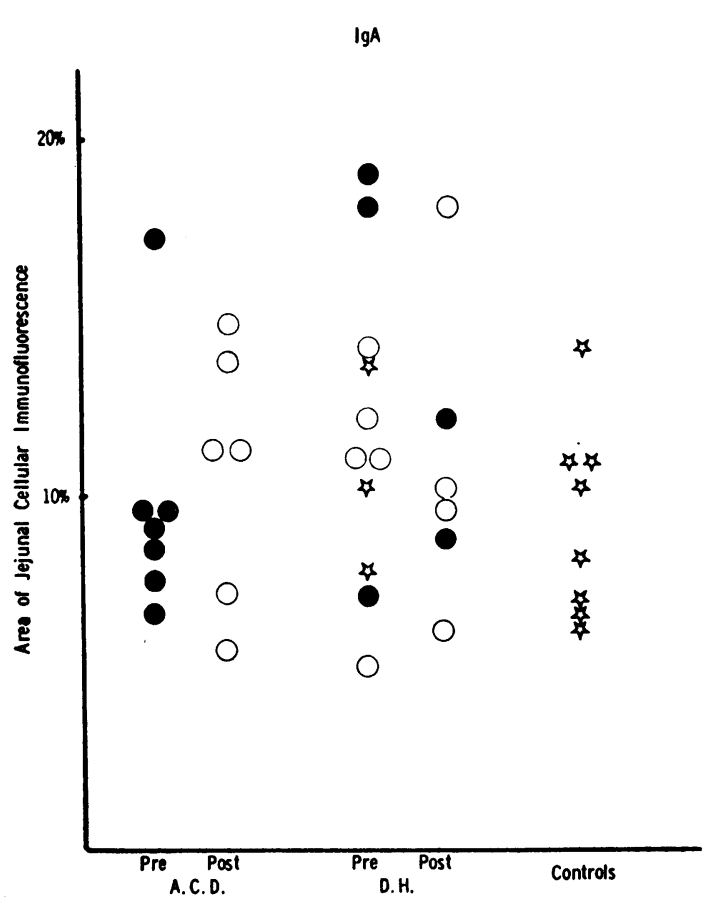

Fig 1

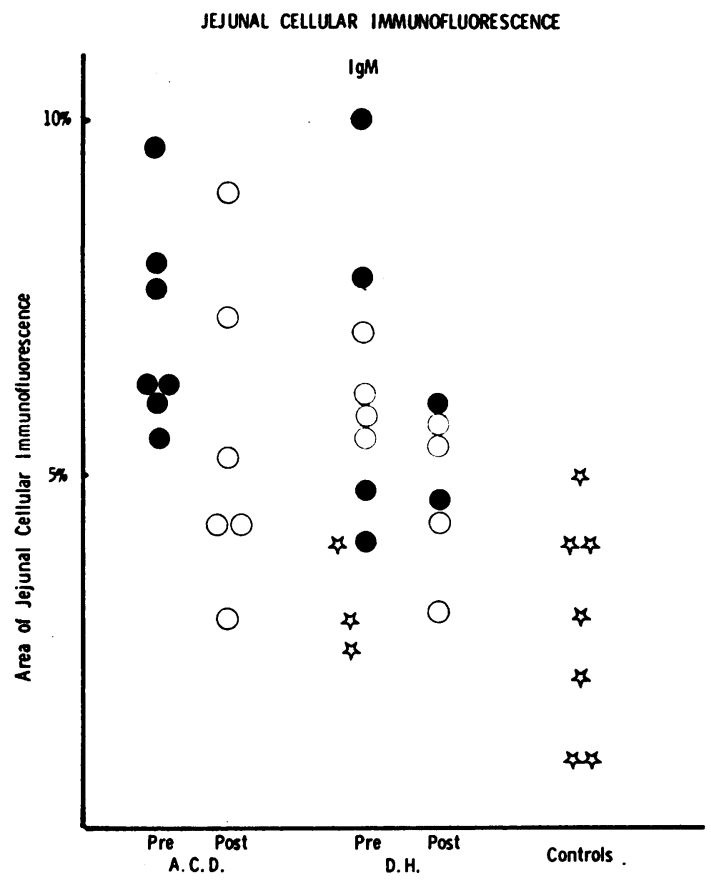

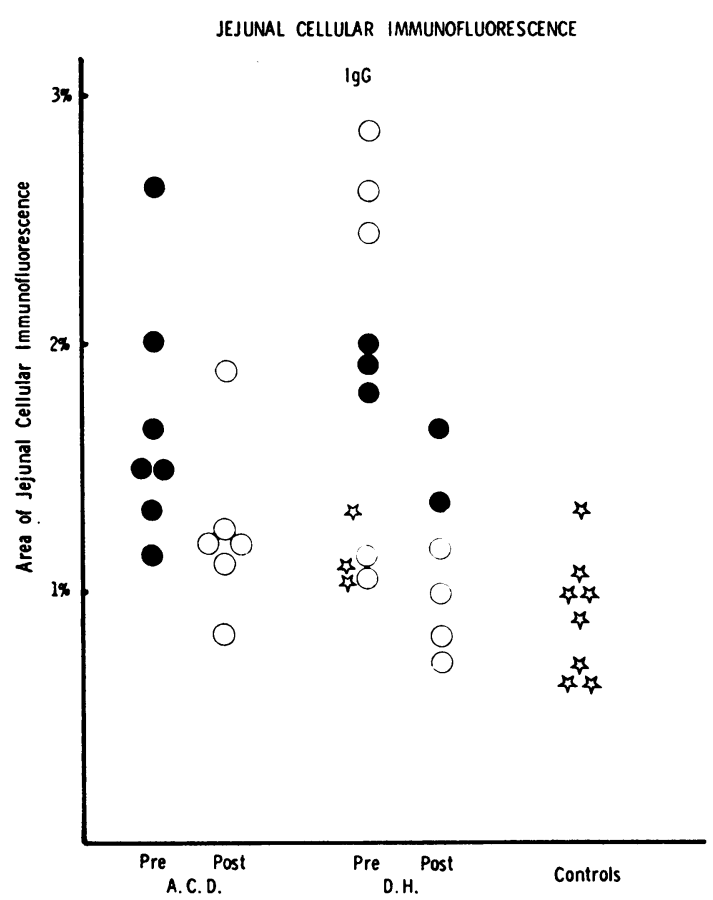

Fig 2

Fig 3

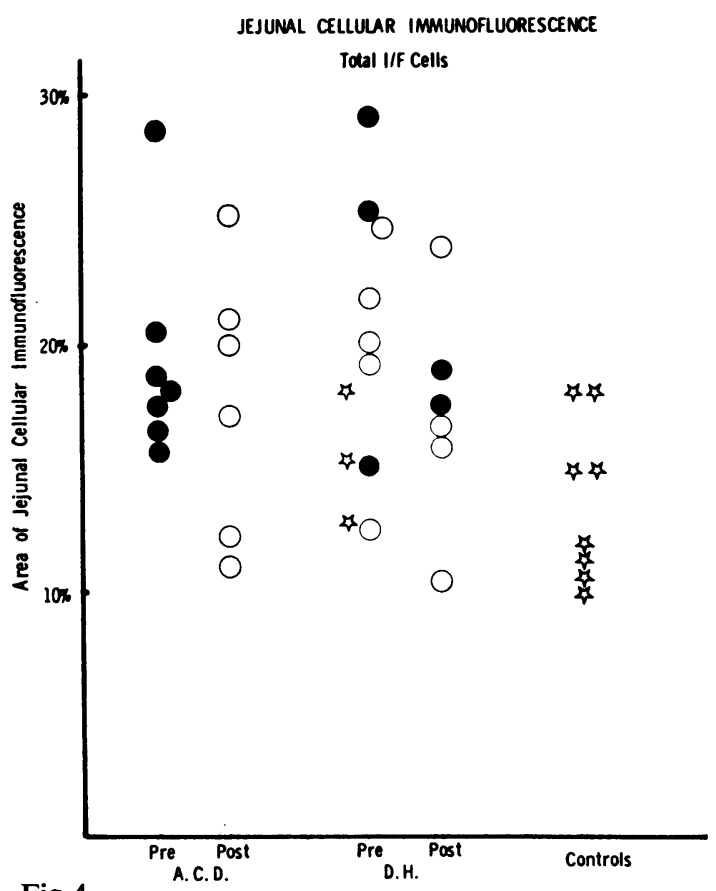

Fig 4

Figs 1-4 Immunoglobulin-containing cells in the jejunal lamina propria.

Adult coeliac disease $(A C D)$ and dermatitis herpetiformis $(D H)$-pretreatment (pre) and posttreatment (post):

- subtotal villous atrophy, $\bigcirc$ partial villous atrophy, thormal mucosa. 
nificantly higher concentrations compared with those with adult coeliac disease $(P<0.01)$ and controls $(P<0.002)$ but the three patients with dermatitis herpetiformis treated with a gluten-free diet were within the normal range. The levels found in adult coeliac disease were intermediate between dermatitis herpetiformis and controls and were significantly higher than the latter $(P<0.05)$.

\section{IgM}

The concentrations in dermatitis herpetiformis were higher than those in adult coeliac disease and the controls $(P<0.002)$. The three treated dermatitis herpetiformis patients were within the normal range. The adult coeliac disease patients had higher concentrations than controls $(P<0.05)$, the greatest values occurring in untreated patients.

\section{IgG}

The concentrations in dermatitis herpetiformis were higher than the control levels $(P<0.05)$. There was no significant difference between both groups of patients nor between adult coeliac disease and controls.

\section{SERUM IMMUNOGLOBULINS}

Levels of IgA and IgG were within normal limits in all patients but $30 \%$ of adult coeliac disease and $21 \%$ of dermatitis herpetiformis patients had IgM concentrations below the normal range of 50 to $170 \mathrm{mg} / 100 \mathrm{ml}$. No correlation was demonstrated between jejunal juice and serum levels of immunoglobulins.

Immunoglobulin-containing cell densities in the jejunum did not correlate with immunoglobulin concentrations in the serum. It was not possible to compare cell densities with immunoglobulins in the jejunal fluid as there were too few subjects common to both studies.

Wilcoxon's sum of ranks test was used throughout.

\section{Discussion}

Total numbers of immunoglobulin-containing cells in the jejunal mucosa were increased in untreated adult coeliac disease as previously shown by Søltoft (1970). Patients on a gluten-free diet, however, had lower values and this agrees with the reduction of plasma cells observed after gluten restriction by Holmes, Asquith, Stokes, and Cooke (1973) using routine histological techniques.

The IgM cell increase in adult coeliac disease confirms previous reports (Douglas et al, 1970; Søltoft, 1970) and in two untreated patients reached predominance over $\operatorname{IgA}$ cells, an occurrence also found in other studies (Douglas et al, 1970; Pettingale, 1971).

IgG-containing cells were increased in untreated adult coeliac disease but not to the extent found by Søltoft (1970). Douglas and his colleagues (1970) and Pettingale (1971) found no significant increase. The most likely explanation for these variations is that although attempts have been made in all studies to reduce sampling errors by using areas of maximal cellular immunofluorescence for quantitation, differences may have arisen because of wide variations of cell density from one microscopic field to another. Such errors are proportionally greatest when cell numbers are small such as for IgG. The equal numbers of IgA cells found in adult coeliac disease and controls agrees with Søltoft (1970) but it is at variance with the results of Douglas et al (1970) and Pettingale (1971) who found varying degrees of reduction in adult coeliac disease. A possible explanation for the difference between our results for IgA cells and those of Douglas and his colleagues (1970) is that their controls were normal subjects (Crabbé, Carbonara, and Heremans, 1965), whereas our control group, although having normal jejunal morphology, did have gastrointestinal symptoms and might not have had an entirely normal jejunal IgA cell density. A further possible explanation for these differences is based on the recent findings that untreated childhood coeliac disease is characterized by an increase in $\operatorname{IgA}$ cell numbers in the jejunal mucosa but falling after treatment with a gluten-free diet (Savilahti, 1972). It has been proposed that the decrease in IgA cells found in previous studies in adult coeliac disease results from exhaustion of this cell class (Savilahti, 1972). Presumably intermediate numbers of IgA cells exist at some point in this pathogenesis and it might be that our patients and those of Søltoft (1970) were at this stage. This concept is further supported by the demonstration that although numbers of IgA cells in our treated group of adults did not differ from those in untreated cases, three of the four patients studied serially did show a reduction in IgA cells when on gluten-free diets, as found in childhood coeliac disease (Savilahti, 1972).

There have been no similar previous studies in dermatitis herpetiformis apart from a single case reported by Douglas et al (1970). This patient, with a convoluted jejunal mucosa, had normal numbers of IgM-containing cells in the lamina propria. This is similar to the situation found in our dermatitis herpetiformis patients without jejunal lesions and in five of those with jejunal abnormality. Our investigation demonstrates essentially similar abnormalities of immunoglobulin-containing cells in dermatitis herpetiformis patients who have jejunal lesions to those found in adult coeliac disease, with the same immunological response to gluten restriction in both conditions. 
The comparable increase in IgM cells in untreated adult coeliac disease and dermatitis herpetiformis patients, whether the latter had subtotal or partial villous atrophy, in contrast to the normal numbers found in dermatitis herpetiformis patients without jejunal abnormality, implies that an increase in IgM cell infiltration is a fundamental phenomenon in the pathogenesis of the mucosal lesion. In addition, the lower IgM cell numbers in treated cases and reduction in IgM cells following treatment in the serially studied patients suggests that the IgM cell response is in part due to the presence of gluten in the diet.

Increased IgM cell infiltration of the jejunal mucosa is not, however, exclusive to adult coeliac disease and dermatitis herpetiformis, having been demonstrated in infectious enteritis (Søltoft and Søeberg, 1972) and ulcerative colitis (Søltoft, 1969), in both of which a comparable morphological abnormality of the jejunal mucosa to that of adult coeliac disease and dermatitis herpetiformis is only rarely seen. It seems, therefore, that an increased IgM response alone is not the complete explanation for the mucosal lesion of both these conditions.

The significantly higher concentration of $\operatorname{IgA}$ and IgM in the jejunal fluid in dermatitis herpetiformis compared with those in adult coeliac disease and controls confirms the recent report by McClelland and his colleagues (1972). We have also confirmed the raised levels of IgA (Thompson, Asquith, and Cooke, 1970) and IgM(Thompsonet al, 1970; Douglas et $a l, 1970$ ) in adult coeliac disease. The increase in the IgM in the luminal fluid may reflect the increased numbers of $\operatorname{IgM}$ cells in the mucosa in these two conditions. Raised IgA concentrations in the jejunal fluid cannot be explained by an increase in IgA cell densities although Douglas et al (1970) have pointed out that even a decrease in density of IgA cells is compatible with an absolute increase in numbers of cells.

The greater concentration of jejunal fluid immunoglobulins in dermatitis herpetiformis than in adult coeliac disease is difficult to explain and has recently been discussed by McClelland and his colleagues (1972) who consider that coexistent achlorhydria may be implicated in some of their patients. Although no difference could be demonstrated in the IgA cell population in groups of patients with both disorders, three patients with dermatitis herpetiformis had values 2 standard deviations above the mean of controls and it is possible that these patients represent the mucosal counterpart of the greatly elevated fluid concentrations of IgA found in some patients with dermatitis herpetiformis.

In conclusion, it appears likely from our comparative study of adult coeliac disease and dermatitis herpetiformis that similar immunological processes are involved in the pathogenesis of the mucosal lesion in both conditions.

We wish to thank Dr Barbara Smith, Mr Adrian Pirson, and Mrs Susan Joyce for their technical assistance.

M.L.S. was on an elective research year from the London Hospital.

\section{References}

Asquith, P., Thompson, R. A., and Cooke, W. T. (1969). Serum immunoglobulins in adult coeliac disease. Lancet, 2, 129-131.

Brandtzaeg, P., Fjellanger, I., and Gjeruldsen, S. T. (1970). Human secretory immunoglobulins. I. Salivary secretions from individuals with normal or low levels of serum immunoglobulins. Scand. J. Haematol., Suppl. 12.

Brow, J. R., Parker, F., Weinstein, W. M., and Rubin, C. E. (1971), The small intestinal mucosa in dermatitis herpetiformis: Severity and distribution of the small intestinal lesion and associated malabsorption. Gastroenterology, 60, 355-361.

Crabbé, P. A., Carbonara, A. O., and Heremans, J. F. (1965). The normal human intestinal mucosa as a major source of plasma cells containing IgA. Lab. Invest., 14, 235-248.

Doe, W. F., Booth, C. C., and Brown, D. L. (1973). Evidence for complement binding immune complexes in adult coeliac disease, Crohn's disease, and ulcerative colitis. Lancet, 1, 402403.

Douglas, A. P., Crabbe, P. A., and Hobbs, J. R. (1970). Immunochemical studies of the serum, intestinal secretions, and intestinal mucosa in patients with adult celiac disease and other forms of the celiac syndrome. Gastroenterology, 59, 414-425.

Fraser, N. G., Dick, H. M., and Crichton, W. B. (1969). Immunoglobulins in dermatitis herpetiformis and various other skin diseases. Brit. J. Dermat., 81, 89-95.

Fry, L., Keir, P., McMinn, R. M. H., Cowan, J. D., and Hoff brand, A. V. (1967). Small intestinal structure and function and haematological changes in dermatitis herpetiformis. Lancet, 2, 729. 734.

Hobbs, J. R., Hepner, G. W. (1968). Deficiency of $\gamma$ M globulin in coeliac disease. Lancet, 1, 217-220.

Holmes, G. K. T., Asquith, P., Stokes, P. L., and Cooke, W. T. (1973). Cellular infiltrate of jejunal biopsies in adult coeliac disease (ACD) in relation to gluten withdrawal. Gut, 14, 429.

McClelland, D. B. L., Barnetson, R. S. C., Parkin, D. M., Warwick, R. R. G., Heading, R. C., and Shearman, D. J. C. (1972). Small intestinal immunoglobulin levels in dermatitis herpetiformis. Lancet, 2, 1108-1110.

Marks, J., Shuster, S., and Watson, A. (1965). Small bowel changes in dermatitis herpetiformis. Lancet, 2, 1280-1282.

Marks, R., Whittle, M. W., Beard, R. J., Robertson, W. B., and Gold, S. C. (1968). Small bowel abnormalities in dermatitis herpetiformis. Brit. med. J., 1, 552-555.

Mowbray, J. F., Hoffbrand, A. V., Holborow, E. J., Seah, P. P., and Fry, L. (1973). Circulating immune complexes in dermatitis herpetiformis. Lancet, 1, 400-402.

Nairn, R. C. (1964). Fluorescent Protein Tracing, 2nd. ed., p. 120. Livingstone, Edinburgh.

Pettingale, K. W. (1971). Immunoglobulin containing cells in the coeliac syndrome. Gut, 12, 291-296.

Savilahti, E. (1972). Intestinal immunoglobulins in children with coeliac disease. Gut, 13, 958-964.

Seah, P. P., Fry, L., Hoff brand, A. V., and Holborow, E. J. (1971). Tissue antibodies in dermatitis herpetiformis and adult coeliac disease. Lancet, 1, 834-836.

Søltoft, J. (1969). Immunoglobulin containing cells in normal jejunal mucosa and in ulcerative colitis and regional enteritis. Scand. J. Gastroent., 4, 353-360.

Søltoft, J. (1970). Immunoglobulin containing cells in non-tropical sprue. Clin. exp. Immunol., 6, 413-420.

Søltoft, J., and Søeberg, B. (1972). Immunoglobulin containing cells in the small intestine during acute enteritis. Gut, 13, 535-538.

Thompson, R. A., Asquith, P., and Cooke, W. T. (1970). Immunoglobulin content of jejunal fluid in coeliac disease and other gastrointestinal diseases. Abstracts of the.IVth World Congress of Gastroenterology, Copenhagen, p. 8. 